Illinois State University

ISU ReD: Research and eData

Milner Library Programs

Milner Library

Fall 2011

\title{
Louisa May Alcott: The Woman Behind Little Women
}

Julie Derden

Illinois State University, jmderde@ilstu.edu

Follow this and additional works at: https://ir.library.illinoisstate.edu/mlbpro

Part of the Library and Information Science Commons

\section{Recommended Citation}

Derden, Julie, "Louisa May Alcott: The Woman Behind Little Women" (2011). Milner Library Programs. 1. https://ir.library.illinoisstate.edu/mlbpro/1

This Book is brought to you for free and open access by the Milner Library at ISU ReD: Research and eData. It has been accepted for inclusion in Milner Library Programs by an authorized administrator of ISU ReD: Research and eData. For more information, please contact ISUReD@ilstu.edu. 


\section{Library Final Report: Louisa May Alcott}

This form is also available in the online site support notebook (www.ala.org/louisamayalcott).

Please note: This report must be returned to the address below within 30 days of your last Louisa May Alcott program. Reporting is a requirement for all projects organized by the American Library Association. Failure to make a timely final report may affect your library's opportunities to take part in other ALA Public Programs Office projects. Please use extra pages if necessary.

Milner Library

Library: Illinois State University

City/State: Normal IL

\section{A) Public programs}

Please provide a description of your programs (include program title, format, and presenter for all programs; use extra space if necessary).

\section{Louisa May Alcott: Through Her Eyes}

A community-wide library event focusing on the life, work, and times of Louisa May Alcott

Date presented: November 29, 2011 (Bloomington Public Library)

Description: Louisa May Alcott's Birthday Party!

A $2 \frac{1}{2}$ hour celebration of (what would have been) Louisa May Alcott's $179^{\text {th }}$ birthday, including stories from Louisa May Alcott's time period and works, a Civil War soldier impersonator in complete military dress, period dancing by the Civil War Dance Society (including audience participation), a clove-studded pomander orange craft, topped off with singing of "Happy Birthday" to our author honoree and apple cake and hot apple cider from Curtis Orchards in UrbanaChampaign and remarks from our scholar

Total

attendance: $\mathbf{4 5}$ Adults: 40 YA: 3 Children: 2

2. Louisa May Alcott Wrote That?

Reading and scholar-led discussion of Alcott's lesser-known works

Date presented: November 15, 2011 (Normal Public Library)

Description: Lead scholar Roberta Trites, two Ph.D. students, and a newly 
graduated

provided lively discussions of
PhD. student from the Department of English the following Alcott titles:

Hospital Sketches, led by new $\mathrm{PhD}$. graduate

Moods, led by PhD. candidate

Work, led by PhD. candidate

A Modern Mephistopheles, led by Dr. Roberta Tries

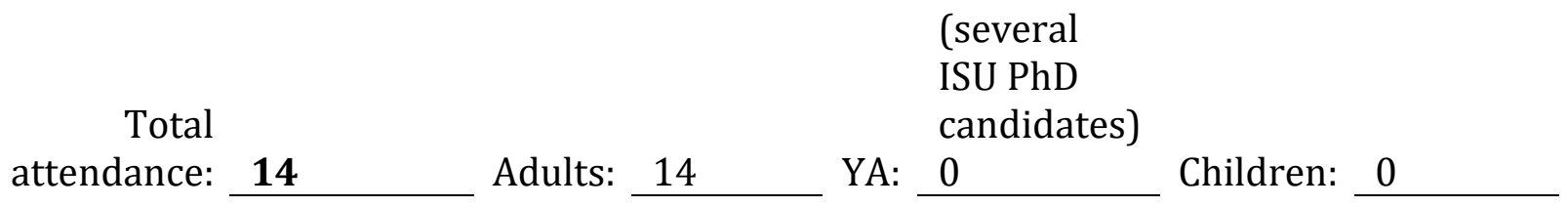

3. Louisa May Alcott: Literary Phenomenon and Social Reformer

Date presented: October 11, 2011 (Milner Library)

Description: Friends of Milner Library Fall Speaker - Dr. Roberta Trites

Speech : Behind Louisa's Mask: Discovering the Real Louisa May Alcott

Hour-long lecture enthusiastically delivered and received by a huge crowd of community members, students, and colleagues of our lead scholar (available on our website as a podcast; link follows in report)

Total

(many

ISU

attendance: $\mathbf{1 7 0}$

Adults: 170

YA: students) Children: 0

4. Film screening - Louisa May Alcott: The Woman Behind Little Women

Date presented: September 17, 2011 (Bloomington Public Library)

October 1, 2011 (Peoria Public Library)

October 29, 2011 (Normal Public Library)

Description: Film viewing/scholar remarks after each viewing

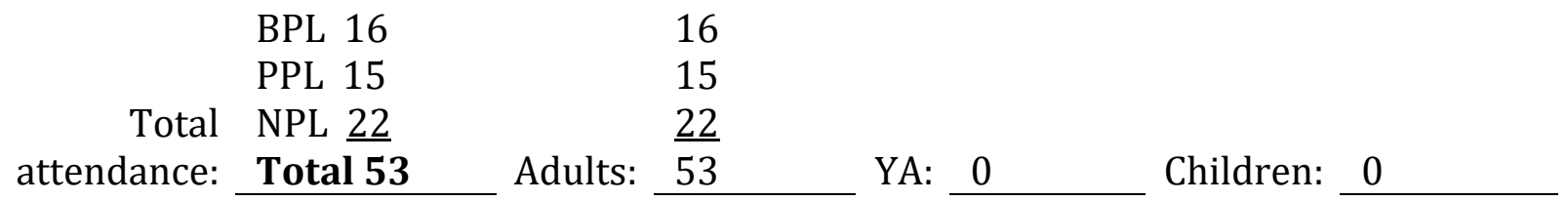

5. Reading and discussion of biography Louisa May Alcott: The Woman Behind Little Women

Date presented: October 6, 2011 (Bloomington Public Library)

Description: Non-fiction book club at BPL discussing the Reisen biography with scholar

Total

attendance: 7

Adults: 7

YA: 0

Children: 0 


\section{Please add other programs sponsored by the library.}

Date presented: September 10, 2011 (Bloomington Public Library)

October 15, 2011 (Peoria Public Library)

Description: Twin City Tale Spinners

"Stories and Puppets and Treats...Oh, My!"

See report from Twin-City Tale Spinners for the details of both

programs

$\begin{array}{ccccc} & \text { BPL } 54 & 42 & 2 & 10 \\ \text { Total } & \text { PPL } \underline{12} & \underline{12} & 0 & 0\end{array}$

attendance: $\quad$ Total 66 Adults: $54 \quad$ YA: 2 Children: 10

7. Please add other programs sponsored by the library.

Date presented: Non-Fiction Book Club (Peoria Public Library)

Description: Discussion led by our lead scholar of John Matteson's Eden's Outcasts, preceded by a one-hour talk by our lead scholar on

Transcendentalism

$\begin{array}{rlr} & \text { Talk } 21 & 21 \\ \text { Total } & \text { Book } \underline{15} \\ \text { Total } \mathbf{3 6}\end{array}$ Adults: $\begin{aligned} & \underline{15} \\ & \text { attendance: YA: } 0 \quad \text { Children: } 0\end{aligned}$

8. Date presented: October 22, 2011 (Peoria Public Library - Main Library and North Branch)

Description: $\quad$ Tea Ladies, Inc. - Period-dress and serving of tea, held in the morning and afternoon at PPL's Main and North Branch libraries

[2 appearances]

\begin{tabular}{|c|c|c|c|c|c|}
\hline $\begin{array}{r}\text { Total } \\
\text { attendance: }\end{array}$ & $\begin{array}{l}\text { am }-20 \\
\text { pm- }=\frac{8}{28} \\
\text { Total } 28\end{array}$ & Adults: & $\begin{array}{r}20 \\
\frac{8}{28} \\
\end{array}$ & YA: & Children: \\
\hline
\end{tabular}

9. Date presented: October 22, 2011 (Peoria Public Library)

Description: Mother-Daughter Tea

Tea and book discussion of Flower Fables by PPL librarian and "Dress the Dummy" hands-on example of period clothing (including a corset, etc.)

Total

attendance: 16

Adults: 8

YA: 4

Children: 4

10. Date presented: Civil War Dance Society performance (Peoria Public Library) 
Description: $\quad$ Performance by Civil War dancers, attired in period-authentic style with audience participation of period dance

Total

attendance:

45

Adults: 40

YA: 5

Children: 0

Grand total number of

programs: 14
Total program

attendance: $\mathbf{4 8 0}$

\section{B) Elementary, middle, and high school involvement}

Include descriptions of Louisa May Alcott library programs for children under Section A above. $^{1}$

Total number of SCHOOLS the library worked with:2

Elementary: 0

Middle: 0

High School: 0

Total number of CLASSES the library worked with:

Elementary: 0 Middle: $\underline{0}$ High School: $\underline{0}$

Total number of STUDENTS the library worked with:

Elementary: $\underline{0} \quad$ Middle: $\underline{0}$

High School: 0

\section{C) Funding}

Include sources and actual/in-kind amounts of support for any Louisa May Alcott programs, invitations, printing, events, etc.: ${ }^{3}$

Source: Friends of Milner Library (11/29 Amount: $\$ 250.00$ honorarium)

\footnotetext{
1 The Evergreen Cemetery Walk, hosted annually by the McLean County Museum of History included a vignette of two Civil War doctors, and Louisa May Alcott was mentioned as a young nurse in that sketch. 2,280 students, teachers and chaperones attended this event (free of charge), thanks to the ticket purchases of 2,091 community members.

2 The summer Parks and Recreation programs in Bloomington and Normal work with area schools before the end of classes to encourage attendance at their programs. The attendance numbers reflect that outreach. ${ }^{3}$ We applied for a grant through the ISU Foundation (Fell Trust) for a panel speech of nursing and history scholars, moderated by our lead scholar, but we were not funded for this event.
} 


\begin{tabular}{|c|c|c|c|}
\hline \multirow[t]{2}{*}{ Source: } & Milner Library (absorbed printing costs) & Amount: & $\begin{array}{l}\text { approximately } \\
200.00\end{array}$ \\
\hline & Partner libraries (absorbed printing costs) & Amount: & $\begin{array}{l}\text { approximately } \\
300.00\end{array}$ \\
\hline & & Total: & 750.00 \\
\hline
\end{tabular}

\section{D) Publicity}

Please describe the results of your publicity strategies, and indicate whether or not you were successful. If your library is an academic or special library, describe how you tried to attract public audiences from outside your customary user groups to your programs.

Our public relations (PR) unit at Milner Library led the effort in marketing the program series by contacting the Media Relations Department at Illinois State University (ISU), who then distributed details about the program to 60 media outlets in the larger BloomingtonNormal communities. Trisha Noack at Peoria Public Library contacted the Peoria-based contacts with information about the programming.

Each public library marketed their "site events" to their respective constituent groups and also provided the program series information at each of their libraries.

Brochures with program dates were also available at the Civil War Days event held at the David Davis Mansion in July 2011.

The Friends of Milner Library-sponsored event with lead scholar, Dr. Roberta Trites, was part of ISU's Fall Speakers Program and a media blitz was associated with that series. Dr Trites was interviewed about the life and work of Louisa May Alcott on two local radio stations, WJBC (AM) and WGLT (local NPR-affiliate) - in August and October, respectively.

\section{E) Publicity samples}

Please attach two copies of all library-produced publicity pieces, including posters and flyers, all newspaper articles and other materials such as bibliographies, bookmarks, invitations, etc.; copies of your Louisa May Alcott webpages; and captioned photographs taken at programs if you have them. Send only one copy of CDs and DVDs.

http://library.illinoisstate.edu/podcasts/ - podcast of Dr. Roberta Trites' 10/11/2011 keynote speech on Louisa May Alcott (required element)

http://library.illinoisstate.edu/alcott/ - website with program details that was uploaded by 9/1/2011

Paper copies of publicity will follow with a hard copy of this report. 
Additionally, Peoria Public Library (Main Branch) had a lovely exhibit up for the month of October of local Civil War citizens, with special publicity for the Louisa May Alcott Program Series (photos to follow with hard copy of report).

\section{F) Comments about programs}

Please identify source of comments, e.g., librarian, program participant, presenter or partner organization. Comments are valuable in reports to funders, and we appreciate your reporting them.

From 9/17/2011 film viewing:

"Thanks! A great documentary."

From 10/9/2011 Transcendentalism lecture and discussion of Eden's Outcasts:

"Really appreciate this series offered by PPL [Peoria Public Library]. Thanks!"

From 10/112/2011 lecture by scholar:

"Roberta was great!"

In answer to the question on the survey, "Are you inspired to (re)read more of Louisa May Alcott's works?" Answer was marked "Yes" with the comment, "and also the [Reisen] biography!"

Submitted

by: Julia M. Derden

Phone: $309-438-3442$
Date:

January 23, 2012

E-mail: jmderde@ilstu.edu

Return this form and attachments within 30 days of the closing of your last Alcott program:

Program Coordinator, ALA Public Programs Office, 50 E. Huron St., Chicago, IL 60611 Any questions, please call 312-280-5289 or contact publicprograms@ala.org

Please note: The ALA Public Programs Office sends e-mail acknowledgement of receipt of final reports to the person submitting the report. If you do not receive this e-mail within 10 days of mailing your report, please contact: publicprograms@ala.org.

All Louisa May Alcott libraries are required to submit the NEH programming grant final report form in addition to this final report. NEH report form follows. 